\title{
An experimental study on double-glazed flat plate solar water heating system in Turkey
}

\begin{abstract}
Domestic hot water preparation systems with flat plate solar collectors are widely used in Turkey. In this collector, the temperature difference between the required water temperature and the ambient air temperature increase causes a decrease in the efficiency of the collector. In this study, the use of double glass in order to increase the efficiency of the collector is studied experimentally. The location is in Isparta South West Turkey. Experimental study is conducted in May 2013 at the Suleyman Demirel University, Isparta. The system components are solar simulator, solar collector, tank, circulation pump, flowmeter, thermocouples, data acquisition device and solar sensor. Solar collector system's operating temperature is $50^{\circ} \mathrm{C}$ for winter also summer. The difference between the collector temperature and the ambient air temperature exceeds $25^{\circ} \mathrm{C}$ in many cases, were found to be more efficient double-glazed collectors. When the temperature difference is $40^{\circ} \mathrm{C}$, using double glazing collector is $24 \%$ more efficient than using single glazing collector.
\end{abstract}

Keyword: Collector efficiency; Domestic water heating; Double-glazed solar collector; Turkey 